\title{
PERLINDUNGAN KONSUMEN DALAM TRANSAKSI ELEKTRONIK MELALUI INSTAGRAM
}

\author{
Mutia Rahma Wardani, Joko Priyono, Fifiana Wisnaeni \\ Program Studi Magister Kenotariatan \\ Fakultas Hukum Universitas Diponegoro \\ E-mail: mutiarhm@gmail.com
}

\begin{abstract}
The implementation of buying and selling online one of the interests of the public is Instagram media, where consumers can gather various information about the items to be purchased and compare prices from various regions so that it can facilitate the purchase of the goods. In application, electronic commerce or e-commerce does not have to be face to face or meet when conducting the transaction. Electronic commerce has more complicated terms and conditions compared to traditional trading. Consumer Protection Act concerning consumer rights in carrying out commerce / trade. Problems that often occur in transactions through the media Instagram are very diverse so it needs special attention in providing comfort for consumers and businesses. The purpose of this research is to find out and analyze Consumer Protection in Electronic Transactions via Instagram. The formulation of the problem in this paper concerning forms of consumer rights violations experienced by online shop consumers, as well as electronic transactions through Instagram media can provide legal protection for consumers.
\end{abstract}

Keywords : Buy and Sell; E-commerce; online transaction

\begin{abstract}
Abstrak
Pelaksanaan jual beli secara online salah satu yang diminati oleh masyarakat yaitu media Instagram, dimana konsumen dapat mengumpulkan berbagai informasi mengenai barang yang hendak dibeli dan membandingkan harga dari berbagai wilayah sehingga dapat memudahkan dalam pembelian barang tersebut. Dalam penerapannya, perniagaan elektronik atau e-commerce tidak harus bertatap muka atau bertemu pada saat melakukan transaksi tersebut. Perniagaan elektronik memiliki syarat dan ketentuan yang lebih rumit dibandingkan dengan perdagangan biasanya. Undang-Undang Perlindungan Konsumen tentang hak konsumen dalam menjalankan perniagaan/perdagangan. Permasalahan yang sering terjadi pada transaksi melalui media Instagram sangat beragam sehingga perlu perhatian khusus dalam memberikan kenyamanan bagi konsumen maupun pelaku usaha. Adapun tujuan dilakukannya penelitian ini adalah untuk mengetahui dan menganalisis Perlindungan Konsumen dalan Transaksi Elektronik Melalui Instagram. Rumusan masalah dalam penulisan ini mengenai bentuk pelanggaran hak konsumen yang dialami oleh konsumen online shop, sertatransaksi elektronik melalui media Instagram dapat memberikan perlindungan hukum bagi konsumen.
\end{abstract}

Kata Kunci : Jual Beli; E-commerce; transaksi online 


\section{A. Pendahuluan}

Di era globalisasi komunikasi yang semakin terpadu dan terdepan dengan internet yang menjadi sangat popular dikalangan masyarakat sekarang seakan telah membuat dunia menciut dan memudarkan batas negara berikut peraturan dan tatanan masyarakatnya. (Prana, Azriadi, 2001) Pengaruh globalisasi dengan penggunaan sarana teknologi informasi dan komunikasi telah mengubah pola hidup masyarakat, dan berkembang dalam tatanan kehidupan baru serta mendorong terjadinya perubahan sosial, ekonomi, budaya, keamanan, dan penegakan hukum.

Di Indonesia sendiri, hasil survey Business Intellingence Report (BIRO) menyatakan bahwa sekitar 60\% responden sudah terbiasa berkorespondensi lewat e-mail dan siap bertransaksi secara online. Hasil survei terhadap 420 responden perusahaan UKM yang berlokasi di Jabotabek dengan 80\% responden memiliki investasi di bawah US\$ 1 juta dan 72,5\% membuat dan menggunakan website dengan motivasi utama mendukung kegiatan promosi.(Prana, Azriadi, 2001)

Pesatnya perkembangan internet berdampak pada terbentuknya suatu sistem perdagangan di dunia maya atau disebut sebagai E-commerce (perniagaan elektronik) sebagai suatu basis segala macam bentuk transaksi jual beli. (Putu Dina Marta Ratna Sari, 2019)

Dengan melakukan transaksi perniagaan elektronik dapat memudahkan melakukan transaksi jual beli melalui e-commerce konsumen mempunyai kemampuan untuk mengumpulkan dan membandingkan informasi seperti barang dan jasa secara lebih luas tanpa dibatasi oleh wilayah. Pada penerapannya, perniagaan elektronik atau e-commerce tidak harus bertatap muka atau bertemu pada saat melakukan transaksi tersebut. Perniagaan elektronik memiliki syarat dan ketentuan yang lebih rumit dibandingkan dengan perdagangan biasanya.

Perlu kita ingat bahwa perniagaan elektronik ini bersifat melintasi negara manapun tanpa batas yang tentunya harus memiliki peraturan yang memadai. (Gultom, 2003)

Dapat kita ketahui Electronic Commerce adalah kegiatan bisnis yang menyangkut konsumen, manufaktur, penyediaan pelayanan, dan pedagang perantara (intermediaries) dengan menggunakan jaringan komputer yaitu 
Internet dan meliputi seluruh spectrum kegiatan komersial. (Remy Sjahdeini, 2001) Satu-satunya hukum internet di Indonesia adalah Undang-Undang Nomor 11 Tahun 2008 tentang Informasi dan Transaksi Elektronik.(Undang-Undang Nomor 11 Tahun 2008 tentang Informasi dan Transaksi Elektronik, n.d.)

Dari pernyataan diatas kita ketahui bahwa dalam pelaksanaan transaksi elektronik hak konsumen harus diperhatikan. Menurut KUHPerdata Pasal 1457 jual beli adalah "suatu perjanjian, dengan mana pihak yang satu mengikatkan dirinya untuk menyerahkan suatu kebendaan, dan pihak yang lain untuk membayar harga yang telah dijanjikan". Pada sebuah siste perbiagaan elektronik, terdapat empat kompone yang diperlukan dalam transaksi perniagaan elektronik, yakni pada took, penjual dan pembeli, jasa pengiriman. Transaksi perniagaan elektronik terdapat pihak-pihak yang menjadi subjek hukum dan memiliki hubungn hukum antara pelaku usaha atau penjual (toko online) dengan konsumen, serta ditambah dengan pihak penyedia jasa aplikasi belanja online.(Firman Turmantara, 2016)

Terkait dengan hak konsumen, dalam Undang-Undang Nomor 8 Tahun 1999 tentang Perlindungan Konsumen pada pasal 4 menyebutkan hak-hak konsumen ialah hak atas kenyaman, keamanan dan dan keselamatan; hak untuk memilih barang dan/atau jasa; hak atas informasi yang benar, jelas dan jujur hak untuk didengar pendapat dan keluhannya atas barang dan/atau jasa yang digunakan; hak untuk mendapatkan advokasi, perlindungan dan upaya penyelesaian sengketa perlindungan konsumen; hak untuk mendapat pembinaan dan pendidikan konsumen; hak untuk diperlakukan atau dilayani secara benar dan jujur serta tidak diskriminatif; hak untuk mendapatkan kompensasi, ganti rugi dan/atau penggantian; hak-hak yang diatur dalam ketentuan peraturan perundang-undangan lainnya (Undang-Undang Perlindungan Konsumen Nomor 8 Tahun 1999, n.d.), serta berhubungan dengan Peraturan Bank Indonesia Nomor 16/1/PBI/2014 yang membahas mengenai pihak yang terlibat dalam jual beli melalui media Instagram (Peraturan Bank Indonesia Nomor 16/1/PBI/2014 Tentang Perlindungan Konsumen Jasa Sistem Pembayaran, n.d.).

Mendapatkan informasi tentang barang merupakan hal yang pokok sebelum konsumen tersebut melakukan transaski untuk membelajakan ddana yang dimiliki oleh konsumen tersebut. (Rosmawati, 2018) Telah disebutkan secara jelas dalam Undang-Undang Perlindungan Konsumen tentang hak 
konsumen dalam menjalankan perniagaan/perdagangan. Masalah perlindungan konsumen dalam e-commerce merupakan aspek cukup penting diperhatikan, karena beberapa karakteristik khas e-commerce akan menempatkan pihak konsumen pada posisi yang lemah atau bahkan dirugikan seperti: (Gunawan Widjaja, 2001)

1. The internet merchant tidak memiliki alamat secara fisik di suatu negara tertentu, sehingga hal ini akan menyulitkan konsumen untuk mengembalikan produk yang tidak sesuai dengan pesananan;

2. Konsumen kesulitan mendapatkan jaminan dalam "local follow up service as repair";

3. Produk yang dibeli konsumen ada kemungkinan tidak sesuai dengan local reqruitments.

Seperti contoh kasus dalam masyarakat, para pelaku usaha menawarkan berbagai produk kepada konsumen melalui account instagram mereka. Pelaku usaha menawarkan berbagai barang branded dengan harganya yang murah di banding harga aslinya.

Foto pada account instagram mereka menampilkan foto asli barang bermerek tersebut dengan menjelaskan bahwa produk mereka tersebut adalah kualitas original. Konsumen tertarik untuk membeli barang tersebut. Cara komunikasi antar pelaku usaha dan konsumen adalah dengan melakukan chatting.

Setelah melakukan chatting dan ditemukan kata sepakat antar kedua pihak, dimana konsumen setuju untuk membeli barang tersebut dan pelaku usaha mengirim barang tersebut tentunya setelah konsumen membayarkan sejumlah uang dan biaya pengirim ke nomor rekening pelaku usaha.

Biasanya pelaku usaha akan meminta bukti pembayaran yang telah dilakukan oleh konsumen, yaitu dengan mengirimkan foto bukti pembayaran tersebut di room chat mereka. Kemudian barang akan dikirim dan konsumen akan meminta nomor resi pengiriman barang mereka (sebagai bukti bahwa barang benar-benar telah dikirim). Namun setelah tiga sampai empat hari menunggu, barang yang datang tidak sesuai dengan gambar. Pada gambar yang tertera di account instagram tersebut sendal Havaianas yang ditawarkan berwarna emas pada tulisan mereknya, sedangkan saat sendal tersebut sampai mereknya tidak berwarna emas sebagaimana yang dijanjikan oleh pelaku usaha. 
Konsumen merasa sangat rugi akan hal ini, karena pelaku usaha memberikan berbagai alasan dan respon yang diberikan oleh pelaku usaha sangat lambat tak secepat saat pemesanan.

Contoh barang diatas adalah sandal yang bermerek Havaianas. Sedangkan masih banyak lagi contoh seperti diatas, tidak hanya sandal, baju juga ada yang menjadi kasus tersebut. Dilihat dari banyaknya kasus seperti contoh di atas, pihak konsumen jelas sangat dirugikan. Perlindungan hukum terhadap hak konsumen tidak terpenuhi sebagaimana yang disebutkan dalam Pasal 4 UndangUndang Nomor 8 Tahun 1999 Tentang Perlindungan Konsumen.

Berdasarkan latar belakang diatas, Penulis ingin menganalisis perihal Perlindungan Konsumen dalan Transaksi Elektronik Melalui Instagram. Rumusan masalah dalam penulisan ini adalah sebagai berikut :

1. Bagaimana bentuk pelanggaran hak konsumen yang dialami oleh konsumen online shop?

2. Bagaimana bentuk perlindungan hukum bagi konsumen dalam transaksi elektronik melalui Instagram?

Judul : Transaksi Jual Beli Melalui Instagram Ditinjau Menurut Kitab Undang-Undang Hukum Perdata (Risanda Lilho Pangestu, 2019). Permasalahan dalam penelitian bagaimana keabsahan kontrak dalam transaksi jual beli melalui Instagram menurut kitab undang-undang hukum perdata.

Hasil yang diperoleh : Keabsahan kontrak elektronik dalam transaksi jual beli melalui Instagram harus memenuhi ketentuan Pasal 1320 Kitab UndangUndang Hukum Perdata mengenai syarat sahnya kontrak diperlukan empat syarat, yaitu: dibuat berdasarkan kesepakatan para pihak, dibuat oleh mereka yang cakap, suatu hal tertentu, dan sebab yang halal. Pelaksanaan jual beli online melalui Instagram, sangat sulit untuk memastikan bahwa penawaran dengn penerimaan akan sesuai dengan yang disepakati dikarenakan transaksi tersebut tidak dilakukan secara langsung/tatap muka sehingga sulit untuk mengetahui kecakapan baik dari pelaku usaha ataupun konsumen. Hal tersebut dimaksud dalam Pasal 1320 Kitab Undang-Undang Hukum Perdata yaitu syarat kecakapan, dimana syarat kecakapan untuk terjadinya suatu perjanjian dapat dibatalkan melalui putusan pengadilan, hal tersebut apabila salah satu pihak meminta pembatalan perjanjian namun apabila salah satu pihak tidak meminta pembatalan maka perjanjian tersebut tetap berlaku. 
Judul : Perlindungan Hukum Terhadap Konsumen Akibat Kerugian Yang Ditimbulkan leh Pelaku Usaha Toko Online Di Instagram (Ni Made Dewi Intan Lestarini, 2019). Permasalahan dalam penelitian Apakah pelaku usaha toko online tersebut dapat dipertanggungjawabkan atas kerugian yang ditimbulkan dari transaksi secara online. Hasil yang diperoleh: Pertanggungjawaban pelaku usaha toko online terkait telah melakukan kesalahan dalam memberikan informasi dengan apa yang dijual, adalah pelaku usaha toko online harus bertanggung jawab sesuai dengan UUPK Pasal 19 ayat (1).

Judul : Perlindungan Hukum Kepada Konsumen Terhadap Penggunaan Klausula Baku Yang Tercantum Pada Toko Online. (Putu Dina Marta Ratna Sari, 2019) Permasalahan dalam penelitian Bagaimana perlindungan terhadap konsumen yang menerima klausula baku dari toko online.

Hasil yang diperoleh: Perlindungan kepada konsumen tidak serta merta berupa perlindungan fisik konsumen, tetapi meliputi hak-hak yang dimiliki konsumen dengan keabstrakan sifat daripada hak-haknya yang melekat pada konsumen. Undang-undang perlindungan Konsumen menjamin adanya kepastian hukum dalam hal memberikan perlindungan kepada konsumen, khususnya dalam hal transaski jual beli online. Dalam hal melakukan perlindungan konsumen, undang-undang memberikan hak kepada konsumen untuk melakukan penuntutan pada Lembaga peradilan, konsumen juga berhak melakukan penyelesaian secara non litigasi.

\section{B. Metode Penelitian}

Penelitian merupakan suatu usaha untuk menganalisa serta mengadakan konstruksi secara metodologis, sistematis dan konsisten. Penelitian merupakan sarana yang digunakan untuk memperkuat, membina serta mengembangkan ilmu pengetahuan Penelitian hukum merupakan suatu kegiatan ilmiah, yang didasarkan pada metode, sistematika, dan pemikiran tertentu, yang bertujuan untuk mempelajari satu atau beberapa gejala hukum tertentu, dengan jalan menganalisanya. Selain itu, juga diadakan suatu pemecahan atas permasalahanpermasalahan yang timbul di dalam gejala yang bersangkutan.(Soekanto, 2005)

Metode Pendekatan penelitian yang digunakan oleh Penulis adalah penelitian hukum empiris, dimana pada penelitian ini objek yang akan diteliti pada awalnya adalah data sekunder yang kemudian dilanjutkan dengan 
penelitian terhadap data primer di lapangan, atau terhadap masyarakat tentang "Perlindungan Konsumen dalam Transaksi Elektronik Melalui Instagram”.

\section{Hasil Dan Pembahasan}

\section{Bentuk pelanggaran hak konsumen yang dialami oleh konsumen} Online Shop di Instagram

Diperlukan perlindungan hukum bagi warga Negara terhadap tindakan hukum pemerintah. Menurut Sjachran Basah, perlindungan terhadap warga Negara diberikan bila sikap tindak administrasi Negara itu menimbulkan kerugian terhadapnya, sedangkan perlindungan terhadap administrasi Negara itu sendiri dilakukan terhadap sikap tindaknya dengan baik dan benar menurut hukum baik tertulis maupun tidak tertulis. (Sjachran Basah, 1992)

Pembahasan tentang bentuk pelanggaran hak konsumen yang dialami oleh konsumen online shop di Instagram dapat diuraikan sebagai berikut:

\section{a. Konsumen Tidak Menerima Barang yang Sesuai dengan yang Dipesan}

Hak untuk melindungi konsumen yang tidak menerima barang sesuai dengan pesanannya akibat informasi dari penjual yang tidak sesuai dengan barang yang dijualnya, hal ini berdasarkan pada Pasal 4 huruf c Undang-Undang Nomor 8 Tahun 1999 Tentang Perlindungan Konsumen menjamin hak atas informasi yang benar, jelas dan jujur mengenai kondisi dan jaminan barang dan/atau jasa. .

Konsumen dapat menggugat pelaku usaha yang melakukan kecurangan dengan memberikan barang yang tidak sesuai dengan foto pada iklan toko online tersebut, dimana hal itu diterangkan dalam Pasal 49 ayat (3) Peraturan Pemerintah Nomor 82 Tahun 2012 Tentang Penyelenggaraan Sistem dan Transaksi Elektronik yang menjelaskan bahwa pelaku usaha wajib memberikan batas waktu kepada konsumen untuk mengembalikan barang yang dikirim apabila tidak sesuai dengan perjanjian atau terdapat cacat tersembunyi.(Peraturan Pemerintah Nomor 82 Tahun 2012 Tentang Penyelenggaraan Sistem dan Transaksi Elektronik, n.d.) 
Batasan Hukum Perlindungan Konsumen, sebagai bagian khusus dari Hukum Konsumen adalah "Keseluruhan asas-asas dan kaidahkaidah yang mengatur dan melindungi konsumen dalam hubungan dan masalah penyediaan dan penggunaan produk konsumen antara penyedia dan penggunaannya, dalam kehidupan bermasyarakat.”(Nasution Az, 1999)

\section{b. Kondisi Barang dalam Keadaan Cacat/Rusak}

Konsumen yang menerima barang dalam keadaan cacat/rusak ataupun konsumen yang menerim barang dengan baik menggambarkan bahwa keadaan barang merupakan hal penting yang menjadiperhatian bagi para konsumen.Keadaan barang yang diterima oleh konsumen menjadi hal yang penting dimana apabila konsumen menerima barang yang cacat/rusak membuat konsumen merasa dirugikan. Hal tersebut dijelaskan, dalam Pasal 4 huruf a Undang-Undang Perlindungan Konsumen yaitu hak atas kenyaman, keamanan dan dan keselamatan dalam mengonsumsi barang dan/atau jasa. Mengenai kenyamanan, keamanan, dan keselamatan bagi konsumen yang melakukan transaksi jual beli merasakan diberikan jaminan dengan adanya ketentuan tersebut.

\section{c. Keterlambatan Pengiriman Oleh Pelaku Usaha}

Salah satu faktor penting dalam transaksi melalui media sosial adalah pengiriman oleh pelaku usaha, dimana ketepatan pengiriman merupakan kepuasan bagi pelanggan. .Jaminan yang didapatkan oleh konsumen merupakan kesepakatan yang harus dipenuhi oleh pelaku usaha untuk memberikan kenyamanan bagi konsumen, dimana hal tersebut merupakan hak konsumen. .Hal tersebut dilakukan untuk menjaga komitmen pelaku usaha dalam melakukan usaha.Kewajiban baik bagi konsumen maupun pelaku usaha yaitu memenuhi jaminan atau garansi yang disepakati antara kedua beah pihak..Apabila pihak yang merasa dirugikan karena jaminan atau garansi tersebut tidak dipenuhi oleh salah satu pihak, maka pihak yang merasa dirugikan berhak untuk menuntut haknya kembali. 
Menurut Pasal 4 Undang-Undang Nomor 8 Tahun 1999 Tentang Perlindungan Konsumen yaitu konsumen berhak atas informasi yang benar, jelas dan jujur mengenai kondisi dan jaminan barang dan atau jasa, dimana keadaan tersebut di atas menjelaskan bahwa pelaku usaha sering melakukan kelalaian yang dilakukan oleh pelaku usaha dengan alasan-alasan tersebut.

Menurut Pasal 19 Undang-Undang Nomor 8 Tahun 1999 yang berbunyi sebagaimana berikut:

1) Pelaku usaha bertanggung jawab memberikan ganti rugi atas kerusakan, pencemaran, dan atau kerugian konsumen akibat mengkonsumsi barang dan atau jasa yang dihasilkan atau diperdagangkan.

2) Ganti rugi sebagaimana dimaksud pada ayat (1) dapat berupa pengembalian uang atau penggantian barang dan/atau jasa yang sejenis atau setara nilainya, atau perawatan kesehatan dan/atau pemberian santunan yang sesuai dengan ketentuan peraturan perundangundangan yang berlaku.

3) Pemberian gantirugi dilaksanakan dalam tenggang waktu 7 (tujuh) hari setelah tanggal transaksi.

4) Pemberian ganti rugi sebagaimana dimaksud pada ayat (1) dan ayat (2) tidak menghapuskan kemungkinan adanya tuntutan pidana berdasarkan pembuktian lebih lanjut mengenai adanya unsur kesalahan.

5) Ketentuan sebagaimana dimaksud pada ayat (1) dan ayat (2) tidak berlaku apabila pelaku usaha dapat membuktikan bahwa kesalahan tersebut merupakan kesalahan konsumen.

Hal ini juga dapat dikategorikan dalam tindakan yang dapat merugikan konsumen dalam pengertian bahwa transaksi yang telah disepakati tidak semestinua pengiriman barang menjadi tidak sesuai dengan yang dipesan oleh konsumen baik secara mutu, kualitas dan jenis barang tersebut. Ancaman pidana adanya penipuan dalam pasal 378 Kitab Undang-Undang Hukum Pidana, yang berbunyi: (Kitab UndangUndang Hukum Pidana, n.d.) 
"Barang siapa dengan maksud untuk menguntungkan diri sendiri atau orang lain secara melawan hukum, dengan memakai nama palsu atau martabat palsu, dengan tipu muslihat, ataupun rangkaian kebohongan, menggerakkan orang lain untuk menyerahkan barang sesuatu kepadanya, atau supaya memberi hutang rnaupun menghapuskan piutang diancam karena penipuan dengan pidana penjara paling lama empat tahun."

Berdasarkan Undang-Undang Nomor 8 Tahun 1999 Tentang Perlindungan Konsumen menjadi pedoman dalam hal ini. Apabila pelaku usaha tersebut terbukti benar merugikan konsumen, maka tindakan administratif yang diambil oleh pemerintah dapat dijadikan alat bukti bagi konsumen yang dirugikan. Sehingga alat bukti terbut dapat digunakan oleh konsumen dan berarti memberi kemudahan bagi konsumen dalam mengajukan gugatan perkaranya. Sanksi administratif berupa penetapan ganti rugi paling banyak Rp. 200.000,- (dua ratus ribu rupiah) apabila pelaku usaha meelanggar Pasal 19 ayat (2), ayat (3) Undang-Undang Nomor 8 Tahun 1999 Tentang Perlindungan Konsumen (sebagaimana yang telah di sebutkan diatas tentang bunyi pasalnya), pasal 20 yang berbunyi: (Undang-Undang Nomor 8 Tahun 1999 tentang Perlindungan Konsumen, n.d.)

"Pelaku usaha periklanan bertanggung jawab atas iklan yang diproduksi dan segala akibat yang ditimbulkan oleh iklan tersebut."

Pasal 50 Undang-Undang Nomor 8 Tahun 1999 Tentang Perlindungan Konsumen yang berbunyi:

"Badan penyelesaian sengketa konsumen sebagaimana dimaksud dalam Pasal 49 ayat (1) terdiri atas:

a. ketua merangkap anggota;

b. wakil ketua merangkap anggota;

c. anggota.

Serta pasal 26 Undang-Undang Nomor 8 Tahun 1999 Tentang Perlindungan Konsumen yang berbunyi: "Pelaku usaha yang memperdagangkan jasa wajib memenuhi jaminan dan/atau garansi yang disepakati dan/atau yang diperjanjikan.” 
Kendala utama yang dihadapi dalam pembuktian perkara seperti ini adalah tidak adanya pengawasan terhadap barang atau jasa yang ditawarkan melalui internet apakah telah memenuhi standar konsumen atau belum.

Dari hasil penelitian diatas, diketahui bahwa kedudukan konsumen selalu lemah bila dibandingkan dengan penjual barang atau jasa. Oleh karena itu, Pasal 19, Pasal 20, Pasal 21, Pasal 24 sampai Pasal 27 Undang-Undang Nomor 8 Tahun 1999 Tentang Perlindungan Konsumen mengatur tentang pertanggung jawaban pelaku usaha dapat dipergunakan selama pelanggaran hak-hak konsumen yang dilakukan oleh pelaku usaha dalam transaksi elektronik masih ada kolerasinya.

Intinya, bentuk perlindungan konsumen dalam transaksi elektronik mengharuskan setiap pelaku usaha memberikan ganti rugii kepada konsumen yang mengalami kerugian akibat perbuatan yang sengaja maupun tidak sengaja.

Barang yang tidak sesuai pesanan diganti dengan barang yang sesuai pesanan adalah cara paling efektif dan yang paling menguntungkan bagi konsumen dan pelaku usaha yang dirugikan. Efisiensi disini dimaksudkan adalah dapat menghemat biaya dan waktu dan agar dimaksudkan juga agar pelaku usaha tersebut tetap menjalankan usahanya.

\section{d. Kontrak Elektronik}

Agar terlaksana transaksi elektronik yang baik dan benar maka kontrak elektronik akan sangat membantu. Transaksi jual beli dilakukan secara online dan berdasarkan Undang-Undang Nomor 11 Tahun 2008 Tentang Informasi dan Transaksi Elektronik dan Peraturan Pemerintah Nomor 82 Tahun 2012 Tentang Penyelenggaraan Sistem dan Transaksi Elektronik tetap diakui sebagai transaksi elektronik yang dapat dipertanggungjawabkan.(Peraturan Pemerintah Nomor 82 Tahun 2012 Tentang Penyelenggaraan Sistem dan Transaksi Elektronik, n.d.) Persetujuan konsumen untuk membeli barang secara online dengan cara melakukan klik persetujuan atas transaksi merupakan bentuk tindakan penerimaan yang menyatakan persetujuan dalam kesepakatan pada transaksi elektronik. Tindakan penerimaan tersebut biasanya didahului 
pernyataan persetujuan atas syarat dan ketentuan jual beli secara online yang dapat kami katakan juga sebagai salah satu bentuk Kontrak Elektronik. Kontrak Elektronik menurut Pasal 47 ayat (2) Peraturan Pemerintah Nomor 82 Tahun 2012 Tentang Penyelenggaraan Sistem dan Transaksi Elektronik dianggap sah apabila:

a. terdapat kesepakatan para pihak;

b. dilakukan oleh subjek hukum yang cakap atau yang berwenang mewakili sesuai dengan ketentuan peraturan perundang-undangan;

c. terdapat hal tertentu; dan

d. objek transaksi tidak boleh bertentangan dengan peraturan perundangundangan, kesusilaan, dan ketertiban umum.

Kontrak Elektronik itu sendiri menurut Pasal 48 ayat (3) Peraturan Pemerintah Nomor 82 Tahun 2012 Tentang Penyelenggaraan System dan Transaksi Elektronik setidaknya harus memuat hal-hal sebagai berikut:

a. data identitas para pihak;

b. objek dan spesifikasi;

c. persyaratan Transaksi Elektronik;

d. harga dan biaya;

e. prosedur dalam hal terdapat pembatalan oleh para pihak;

f. ketentuan yang memberikan hak kepada pihak yang dirugikan untuk dapat mengembalikan barang dan/atau meminta penggantian produk jika terdapat cacat tersembunyi; dan

g. pilihan hukum penyelesaian Transaksi Elektronik.

Dengan karena itu, pada transaksi elektronik yang konsumen lakukan, dapat menggunakan Undang-Undang Nomor 11 Tahun 2008 Tentang Informasi dan Transaksi Elektronik dan/atau Peraturan Pemerintah Nomor 82 Tahun 2012 Tentang Penyelenggaraan Sistem dan Transaksi Elektronik sebagai dasar hukum dalam menyelesaikan permasalahan.

Terkait dengan perlindungan konsumen, Pasal 49 ayat (1) Peraturan Pemerintah Nomor 82 Tahun 2012 Tentang Penyelenggaraan Sistem dan Transaksi Elektronik menegaskan bahwa Pelaku Usaha yang menawarkan produk melalui Sistem Elektronik wajib menyediakan informasi yang lengkap dan benar berkaitan dengan syarat kontrak, produsen, dan produk 
yang ditawarkan. Pada ayat berikutnya lebih ditegaskan lagi bahwa Pelaku Usaha wajib memberikan kejelasan informasi tentang penawaran kontrak atau iklan.

\section{Bentuk perlindungan hukum bagi konsumen dalam transaksi elektronik melalui Instagram}

Dalam transaksi elektronik subjek hukum, dalam hal ini pelaku usaha dan konsumen, melakukan transaksi perdagangan melalui teknologi informasi berupa internet sehingga melahirkan perjanjian.

Dalam perjanjian ada yang disebut dengan dokumen elektronik yang dapat dijadikan sebagai alat bukti elektronik untuk menghindari adanya penyalahgunaan oleh orang yang tidak bertanggung jawab yang dapat digolongkan sebagai kejahatan dalam transaksi elektronik. Maka dari itu dibutuhkan perlindungan hukum bagi para subjek hukum yang melakukan transaksi elektronik ini.

Dalam perjanjian terdapat dokumen elektronik, yang dimana pelaku usaha membuat isi dari dokumen tersebut dan berisikan aturan dan kondisi yang harus dipenuhi oleh para konsumen. Aturan tersebut digunakan sebagai perlindungan hukum bagi kedua belah pihak. Perlindungan hukum bagi kedua belah pihak adalah:

a. Perlindungan hukum untuk pelaku usaha ditekankan dalam hal pembayaran, dimana konsumen diharuskan membayar penuh dan melunaskan pembayaran tersebut dan kemudian melakukan konfirmasi pembayaran baru setelah itu barang akan dikirimkan.

b. Perlindungan hukum bagi konsumen terletak pada garansi berupa pengembalian atau penukaran barang jika barang yang diterima tidak sesuai dengan apa yang dipesan.

Sebagaimana yang kita ketahui sekarang, banyak konsumen yang haknya tidak diperhatikan oleh para pelaku usaha membuat konsumen merasa dirugikan. Dalam kaitannya dengan perkembangan terknologi komunikasi dan informasi dimana barang dan jasa dapat diperdagangkan kepada konsumen tanpa ada batasan wilayah, maka perlindungan konsumen menjadi hal penting dan menarik untuk dibahas.(Makarim, 2004) 
Konsumen dan pelaku usaha merupakan pihak yang harus mendapatkan perlindungan hukum. Namun sering kali posisi konsumen lebih lemah dibandingkan dengan pelaku usaha. Hal ini berkaitan dengan tingkat kesadaran para konsumen terhadap haknya, kemampuan keuangan, dan kemampuan dalam tawar menawar yang cenderung masi rendah. Tata hukum harus bisa menempatkan kedudukan kedua belah pihak di tempat yang sama sehingga mendapat keadilan yang sebenarbenarnya. Konsumen harus dilindungi oleh hukum karena salah satu sifat dan tujuan hukum adalah memberikan pengayoman pada masyarakat yang diwujudkan dalam bentuk kepastian hukum yang menjadi hak konsumen.

Membicarakan tentang hak konsumen, dalam pasal 4 Undang-Undang Nomor 8 Tahun 1999 Tentang Perlindungan Konsumen telah disebutkan jelas apa saja hak-hak konsumen, bunyi pasal tersebut adalah:

a. hak atas kenyaman, keamanan dan dan keselamatan dalam mengonsumsi barang dan/atau jasa;

b. hak untuk memilih barang dan/atau jasa serta mendapatkan barang dan/atau jasa tersebut sesuai dengan nilai tukar dan kondisi serta jaminan barang dan/atau jasa;

c. hak atas informasi yang benar, jelas dan jujur mengenai kondisi dan jaminan barang dan/atau jasa;

d. hak untuk didengar pendapat dan keluhannya atas barang dan/atau jasa yang digunakan;

e. hak untuk mendapatkan advokasi, perlindungan dan upaya penyelesaian sengketa perlindungan konsumen secara patut;

f. hak untuk mendapat pembinaan dan pendidikan konsumen;

g. hak untuk diperlakukan atau dilayani secara benar dan jujur serta tidak diskriminatif (baik secara suku, agama, budaya, daerah, pendidikan, kaya, miskin, dan status social lainnya);

h. hak untuk mendapatkan kompensasi, ganti rugi dan/atau penggantian, apabila barang dan/atau jasa yang diterima tidak sesuai dengan perjanjian atau tidak sebagaiman mestinya;

i. hak-hak yang diatur dalam ketentuan peraturan perundang-undangan lainnya.(Kansil C.S.T, 2002) 
Seperti yang telah dijabarkan diatas, banyak dari pasal 4 tersebut belum diterapkan secara benar dan baik oleh para pihak terkait. Mengenai pelaksaan hak-hak konsumen oleh pelaku usaha di account instagram harus diketahui karena transaksi elektronik telah disepakati tidak bisa diabaikan oleh penjual barang atau jasa dengan alasan apapun.

Pasal 49 ayat (3) Peraturan Pemerintah Nomor 82 Tahun 2012 Tentang Penyelenggaraan Sistem dan Transaksi Elektronik menjelaskan bahwan pelaku usaha wajib memberikan batas waktu kepada konsumen untuk mengembalikan barang yang dikirim apabila tidak sesuai dengan perjanjian atau terdapat cacat tersembunyi. Apabila ternyata barang yang konsumen terima tidak sesuai dengan foto pada iklan toko online tersebut (sebagai bentuk penawaran), konsumen dapat menggugat Pelaku Usaha secara perdata dengan alasan terjadinya wanpretasi atas transaksi jual beli yang Anda lakukan dengan penjual.

\section{Simpulan}

Berdasarkan penjelasan dan pembahasan diatas dapat disimpulkan hal-hal sebagai berikut: Berdasarkan Peraturan Pemerintah Nomor 82 Tahun 2012 Tentang Penyelenggaraan Sistem dan Transaksi Elektronik, Pasal 49 Ayat (3) yang menjelaskan bahwa perlindungan hukum bagi para konsumen yang tidak mendapatkan barang yang sesuai dengan yang dipesan ataupun barang yang dipesan terdapat cacat tersembunyi sehingga pelaku usaha wajib memberikan perjanjian mengenai Batasan waktu untuk konsumen mengembalikan barang tersebut.

Dengan demikian konsumen dapat menggugat pelaku usaha dengan alasan wanprestasi atas transaksi jual beli melalui media sosial secara perdata. Berdasarkan Undang-Undang Nomor 8 Tahun 1999 Tentang Perlindungan Konsumen, sebagaimana disebutkan pada pasal 4 bahwa perlindungan hak bagi konsumen disertai dengan i'tikad baik harus dilakukan dengan baik sehingga menghindari kerugian bagi konsumen. 


\section{DAFTAR PUSTAKA}

Firman Turmantara. (2016). Hukum Perlindungan Konsumen. Malang: Setara Press.

Gultom, E. (2003). Perlindungan Konsumen dalam Transaksi Perdagangan melalui Ecommerce. Jakarta: Penerbit Elips II.

Gunawan Widjaja, A. Y. (2001). Hukum Tentang Perlindungan Konsumen. Jakarta: Gramedia Pustaka Utama.

Kansil C.S.T. (2002). Pokok-Pokok Pengetahuan Hukum Dagang Indonesia. Jakarta: Sinar Grafika.

Makarim, E. (2004). Kompilasi Hukum Telematika. Jakarta: Raja Grafindo.

Nasution Az. (1999). Hukum Perlindungan Konsumen (Suatu Pengantar). Jakarta: Daya Widya.

Prana, Azriadi, G. A. (2001). Hacker Sisi Lain Legenda Komputer. Jakarta: Medikom Pustaka Mandiri.

Rosmawati. (2018). Pokok-Pokok Hukum Perlindungan Konsumen. Jakarta: Kencana.

Sjachran Basah. (1992). Perlindungan Hukum atas Sikap tindak Administrai Negara. Bandung.

Soekanto, S. (2005). Pengantar Penelitian Hukum. Jakarta: UI Press.

(Kitab Undang-Undang Hukum Pidana, n.d.)

Kitab Undang-Undang Hukum Pidana.

Peraturan Bank Indonesia Nomor 16/1/PBI/2014 Tentang Perlindungan Konsumen Jasa Sistem Pembayaran.

Peraturan Pemerintah Nomor 82 Tahun 2012 Tentang Penyelenggaraan Sistem dan Transaksi Elektronik.

Undang-Undang Nomor 11 Tahun 2008 tentang Informasi dan Transaksi Elektronik.

Undang-Undang Nomor 8 Tahun 1999 tentang Perlindungan Konsumen.

Undang-Undang Perlindungan Konsumen Nomor 8 Tahun 1999.

Ni Made Dewi Intan Lestarini. (2019). Perlindungan Hukum Terhadap Konsumen Akibat Kerugian Yang Ditimbulkan leh Pelaku Usaha Toko Online Di Instagram. Universitas Udayana.

Putu Dina Marta Ratna Sari. (2019). Perlindungan Hukum Kepada Konsumen Terhadap Penggunaan Klausula Baku Yang Tercantum Pada Toko Online. Universitas Udayana.

Remy Sjahdeini. (2001). E-Commerce Tinjauan dari Perspektif, dalam Hukum Bisnis 
Vol. (12). Yayasan Pengembangan Hukum Bisnis.

Risanda Lilho Pangestu. (2019). Transaksi Jual Beli Melalui Instagram Ditinjau Menurut Kitab Undang-Undang Hukum Perdata. Universitas Sebelas Maret Surakarta. 